This item was submitted to Loughborough's Research Repository by the author.

Items in Figshare are protected by copyright, with all rights reserved, unless otherwise indicated.

\title{
Fabrication of porous bioactive structures using the selective laser sintering technique
}

PLEASE CITE THE PUBLISHED VERSION

PUBLISHER

Professional Engineering Publishing / @ IMechE

VERSION

VoR (Version of Record)

LICENCE

CC BY-NC-ND 4.0

\section{REPOSITORY RECORD}

Savalani, M.M., L. Hao, Y. Zhang, K.E. Tanner, and Russell A. Harris. 2019. "Fabrication of Porous Bioactive Structures Using the Selective Laser Sintering Technique". figshare. https://hdl.handle.net/2134/4702. 
This item was submitted to Loughborough's Institutional Repository (https://dspace.lboro.ac.uk/) by the author and is made available under the following Creative Commons Licence conditions.

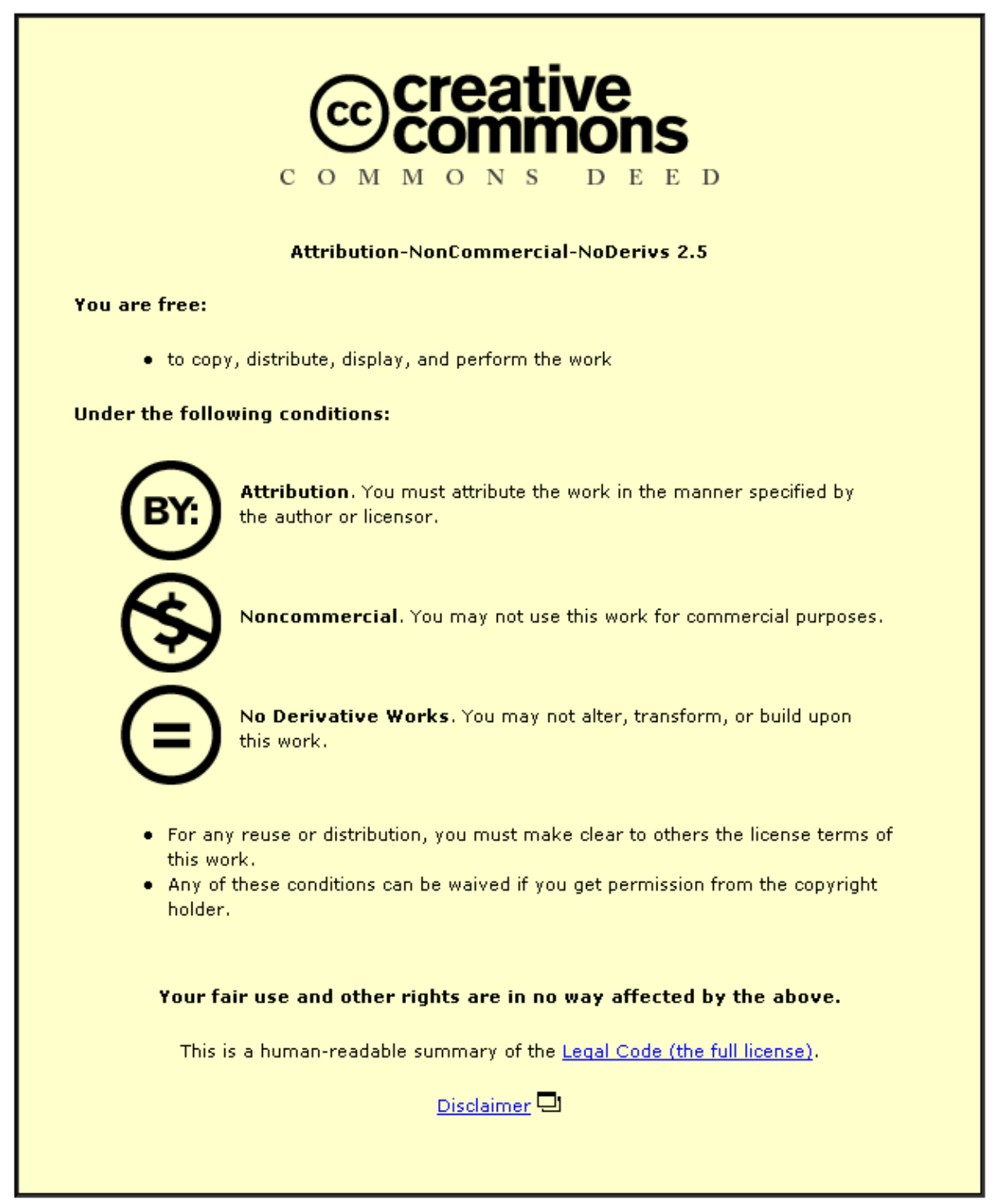

For the full text of this licence, please go to: http://creativecommons.org/licenses/by-nc-nd/2.5/ 


\title{
Fabrication of porous bioactive structures using the selective laser sintering technique
}

M M Savalani ${ }^{1 *}$, L Hao ${ }^{1}$, Y Zhang ${ }^{2}$, K E Tanner ${ }^{2}$, and R A Harris ${ }^{1}$

${ }^{1}$ Wolfson School of Mechanical \& Manufacturing Engineering, Rapid Manufacturing Research Group, Loughborough University, Loughborough, UK

${ }^{2}$ Department of Materials, Queen Mary University of London, London, UK

The manuscript was received on 23 August 2006 and was accepted after revision for publication on 25 July 2007.

DOI: 10.1243/09544119JEIM232

\begin{abstract}
Hydroxyapatite, a ceramic with which natural bone inherently bonds, has been incorporated into a polymer matrix to enhance the bioactivity of implant materials. In order to manufacture custom-made bioactive implants rapidly, selective laser sintering has been investigated to fabricate hydroxyapatite and polyamide composites and their properties investigated. One objective of this research was to identify the maximum hydroxyapatite content that could be incorporated into the matrix, which was sintered at various parameters. The study focused on investigating the control of porosity and pore size of the matrix by manipulating the selective laser sintering parameters of the laser power and laser scan speed. The interception method was used to analyse the internal porous morphology of the matrices which were crosssectioned through the vertical plane. Most notably, all structures built demonstrated interconnection and penetration throughout the matrix. Liquid displacement was also used to analyse the porosity of the matrices. The laser power showed a negative relationship between porosity and variation in parameter values until a critical power value was reached. However, the same relationship for laser scan speed matrices was inconsistent. The effects of the laser power and laser scanning speed on the features of porous structures that could influence cell spreading, proliferation, and bone regeneration are presented.
\end{abstract}

Keywords: rapid manufacturing, selective laser sintering, hydroxyapatite, polyamide, bioactive implants

\section{INTRODUCTION}

Congenital defects, trauma, or destructive surgery such as that required in radical cancer treatments which result in bone loss create a need for skeletal reconstruction. Autografting (transplantation from one location in a patient to another part in the same patient) and allografting (transplantation from a donor to the patient) are the two most common means of transplantation for skeletal repair. However, a number of drawbacks including limited material supply, patient donor site morbidity, and possible

*Corresponding author: Wolfson School of Mechanical \& Manufacturing Engineering, Rapid Manufacturing Research Group, Loughborough University, Loughborough, Leicestershire, LE11 3TU, UK. email: m.m.savalani@lboro.ac.uk transmission of infections have resulted in the need for suitable alternatives $[\mathbf{1}, \mathbf{2}]$.

An alternative to transplantation for skeletal repair is implants. For the last two decades, implant research has pursued the use of bioactive fixation, in which interfacial bonding between the implant and tissue is generated from formation of a layer of biologically active material on the implant surface [3]. Attention has also been placed on custom-made implants. Clinical research has shown that custommade implants have the potential to enhance the longevity of a device by providing a more secure fit, which has not been achieved by conventional manufacturing techniques [4]. Furthermore, the presence of an optimized and selective microstructure would determine the rate of host bone integration by creating an environment in which cells would spread, 
proliferate, and regenerate bone, thus integrating the implant into the body [5]. This deliberate and controlled porosity would further mean that, even if the initial strength and toughness were below that required for long-term use, the ingrown bone would increase the strength of the bone-implant composite by a factor of 3 or 4 [6].

Such complex geometrical features may be achieved by rapid manufacturing (RM). RM is a natural extension of rapid prototyping technologies [7]. These manufacturing processes are capable of producing complex free-form objects directly and automatically from a computer model. RM techniques are capable of constructing parts with good control over the internal and external geometries. Its ability to produce internal structures makes it an ideal technique for manufacturing bioactive implants which would encourage cell spreading, proliferation and bone regeneration $[\mathbf{8}]$.

Selective laser sintering (SLS) has the potential to construct bioactive implants, owing to its capability of processing polymers, ceramics, metals and their composites. SLS is a technique which selectively sinters sequential layers of powder by heat generated from a laser beam. Interaction of the laser beam with the surface of the powder elevates the temperature, causing the particles to fuse together and to form a solid layer [9]. Successive layers of powder are deposited and scanned by the laser. Each sintered layer bonds to the previous layer until, eventually, an entire component is built. Tan et al. [10] and Chua et al. [11] demonstrated the ability of SLS to fabricate physically blended hydroxyapatite (HA)-poly(etherether-ketone) (PEEK) and HA-poly(vinyl alcohol) composites for tissue scaffold development and observed micropores on the scaffold surface. Das and co-workers [12-14] investigated the production of HA-poly-(L-lactic acid) (PLLA) parts by SLS and found that the ultimate compressive strength and elastic modulus were in the lower limits of reported values for cancellous bone. In addition, using computational designs, this technique was used to manufacture tissue-engineering scaffolds with periodic cellular and biomimetic architectures where the smallest predefined pores fabricated by SLS were $800 \mu \mathrm{m}$ for nylon material and $1750 \mu \mathrm{m}$ for polycarbonate material.

Du et al. [15] investigated the influence of various SLS parameters on the microstructure of polymeric parts. Results from the study and other similar work indicate that the laser power and laser scanning speed, which are directly related to the amount of energy imparted on the powder surface, are among the most significant parameters affecting the micro- structure and the physical and mechanical properties of the SLS parts [8]. Often, both these parameters are seen as a function of specific energy density which is denoted by

$$
\begin{aligned}
& \text { Specific energy density }\left(\mathrm{J} / \mathrm{mm}^{2}\right) \\
& =\frac{\text { power }(\mathrm{W})}{\text { velocity }(\mathrm{mm} / \mathrm{s}) \times \text { scan spacing }(\mathrm{mm})}
\end{aligned}
$$

Relatively little work has been done on assessing the morphologies of internal structure in bioactive composite materials by SLS and the ability of control over the internal structure of potential implants to influence cell proliferation, spreading, and tissue regeneration. The work presented in this paper provides an assessment of the internal structure of sintered bioactive ceramic polymer composite materials using SLS for bioactive bone implants. Following the identification of the maximum HA content ratio with composite powders suitable for the sintering, characterization of key operating parameters such as the laser power and laser scanning speed in the SLS process was carried out to determine optimal parameter settings with the aim of producing optimum bioactive structures. The influence of the SLS processing parameters on the microstructure of the fabricated parts, such as the porosity, average pore size, and fraction of optimum pore size for bone regeneration, was investigated.

\section{METHODS}

\subsection{Polyamide, hydroxyapatite raw materials and hydroxyapatite-polyamide composite powders}

For this research, commercial SLS material-grade fine nylon was used as the binder, to isolate and clarify variables within the investigation and to evaluate the viability of using the SLS process to fabricate structures with the maximum HA content possible and to assess the internal structure fabricated.

HA powders (P218R, Plasma Biotal Ltd, UK) with a median particle size $\left(d_{0.5}\right)$ of $3.80 \mu \mathrm{m}$, a specific surface area of $13.54 \mathrm{~m}^{2} / \mathrm{g}$, and a theoretical density of $3.16 \mathrm{~g} / \mathrm{cm}^{3}$ was used for preparing HA-polyamide (PA) composite powders. The HA powders meet the ASTM F1185-88 requirements and have a particle size distribution with at least $90 \mathrm{wt} \%$ below $60 \mu \mathrm{m}$. PA powder (Duraform) from 3D Corporation has a tap powder density of $0.54 \mathrm{~g} / \mathrm{cm}^{3}$, an average particle size of $56 \mu \mathrm{m}$, and a distribution from 25 to $93 \mu \mathrm{m}$; its melting point is $185^{\circ} \mathrm{C}$. These powders were 
blended to produce mixtures with a mix ratio composition of $78 \mathrm{wt} \%$ HA (i.e. 52 vol. \%). Subsequently, the mixtures were compounded in a twin-screw extruder (Betol BTS40L, Betol, Luton, UK) to produce HA-PA composites. The extruded composites were subsequently pelletized in a Betol pelletizer. The pelletized HA-PA composites were powderized in an ultra centrifuge mill (Retsch powderizer, Germany) using a sieve of $0.12 \mathrm{~mm}$ aperture size. Liquid nitrogen was used as a coolant to reduce temperature increases during milling. A detailed description of the fabrication technique has been described in the work by Wang et al. [16]. The resultant HA-PA composite particles were sieved with a sieve of $75 \mu \mathrm{m}$ aperture size (Endecotts Ltd, UK). The sieve was vibrated and rotated to achieve even and welldistributed sieving. To remove any electrostatic effects the sieve shaker was earthed. Particles were vibrated for a period of $15 \mathrm{~min}$. In order to obtain the composites with various HA ratios, pure PA powder was added to the HA-PA composite particles until three composites with $71 \mathrm{wt} \%, 63 \mathrm{wt} \%$, and

Table 1 HA:PA ratios by weight and volume

\begin{tabular}{lll}
\hline HA-PA material & $\begin{array}{l}\text { HA:PA ratio } \\
\text { (wt \%) }\end{array}$ & $\begin{array}{l}\text { HA:PA ratio } \\
\text { (vol \%) }\end{array}$ \\
\hline HA-PA I & $78: 22$ & $52: 48$ \\
HA-PA II & $70: 30$ & $42: 58$ \\
HA-PA III & $64: 36$ & $35: 65$ \\
HA-PA IV & $58: 42$ & $31: 69$ \\
PA & $0: 100$ & $0: 100$ \\
\hline
\end{tabular}

58 wt \% HA were obtained. These weight ratios correspond to the volume ratios shown in Table 1. To ensure uniform distribution the particles were mixed in a tumbler for $3 \mathrm{~h}$ at a rate of $40 \mathrm{r} / \mathrm{min}$.

\subsection{SLS experimental system and processing}

A bespoke SLS experimental system was produced to sinter HA-PA (Fig. 1). The three major benefits of this system are the reduced amount of powdered material required, the superior control over the temperature profile, and the possibility of utilizing various lasers. This system incorporates a powder bed chamber and a $\mathrm{CO}_{2}$ laser system which consists of a Synrad 48-1-28 $\mathrm{CO}_{2}$ continuous-mode laser with a wavelength of $10.6 \mu \mathrm{m}$ and a maximum power of $10 \mathrm{~W}$. The scanning speed of the laser beam may be varied from 0.2 to $10000 \mathrm{~mm} / \mathrm{s}$. The laser beam was focused to a spot size of $0.193 \mathrm{~mm}$ at a focal length of $241 \mathrm{~mm}$. The powder bed chamber consists of powder building and feeding cylinders (103 mm diameter), a powder deposition system, a heater, and temperature measurement and control devices. The chamber is contained within a polycarbonate box in conjunction with a computer control station. During the process, nitrogen gas is purged into the chamber to create an inert atmosphere and to maintain oxygen levels below 5 per cent.

A fixed variable-operation window was identified for the sintering of HA-PA and then selected parameters were used to study the effects of laser power and laser scanning speed on the open porosity, aver-

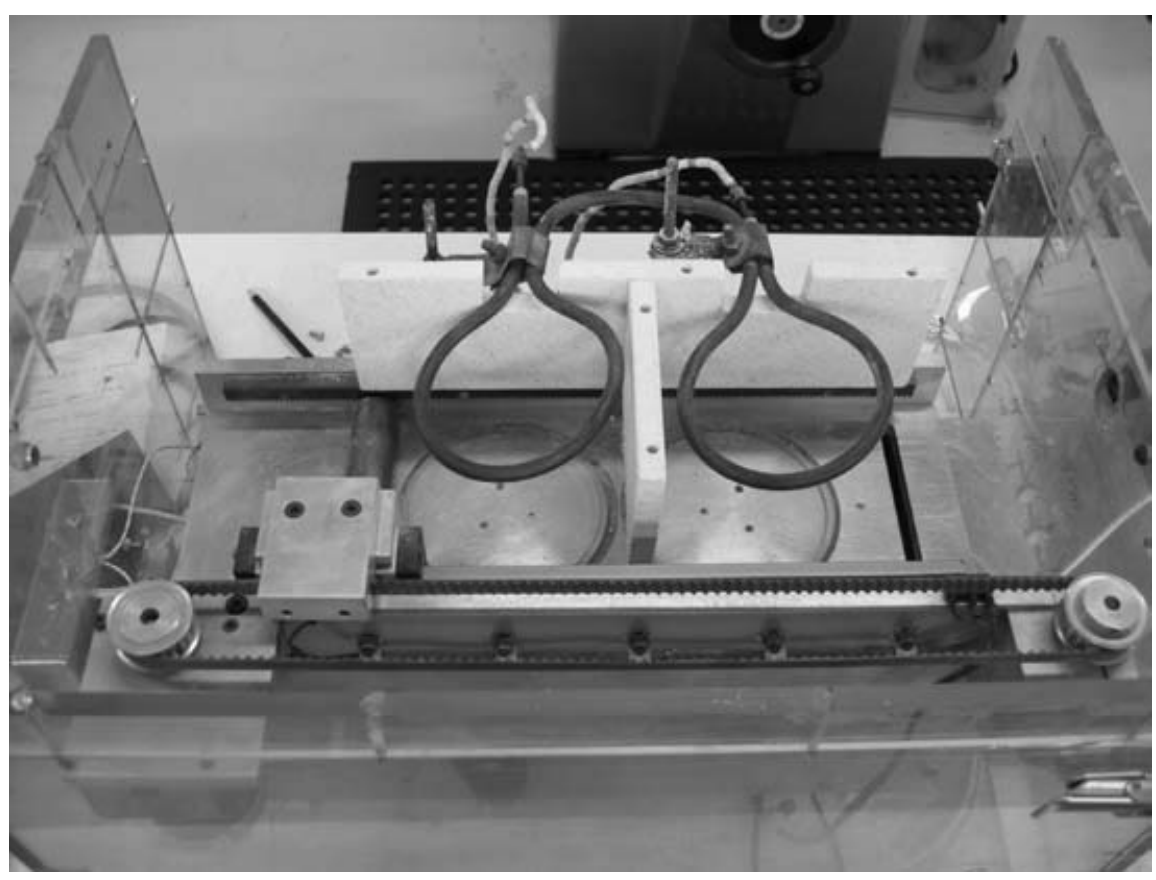

Fig. 1 SLS system showing the two heater rings above the build and feed cylinders 
age pore size, and fraction of optimum pore sizes for bone regeneration. Before laser sintering, the powders are prelayered and preheated by the overhead heater to $166{ }^{\circ} \mathrm{C}$, which is $6{ }^{\circ} \mathrm{C}$ below the HA-PA glazing temperature of $172{ }^{\circ} \mathrm{C}$ to reduce the thermal stress induced, which results in curling of the sintered parts. The preheating of the powder helps to lower the energy required from the laser and to ensure the stability of the processed parts during the sintering process [17]. The temperature and output of the heater were maintained by a feedback loop integrated with an infrared sensor.

The sizes of the HA-PA samples produced were $1 \mathrm{~mm} \times 3 \mathrm{~mm} \times 21 \mathrm{~mm}$. These are the dimensions required for dynamic mechanical analysis (DMA) and were chosen to enable any further mechanical assessments to be made. The HA-PA specimens consist of six selective laser sintered layers with $0.15 \mathrm{~mm}$

Table 2 Parameter settings

\begin{tabular}{lll}
\hline & $\begin{array}{l}\text { Constant or } \\
\text { variable }\end{array}$ & Value \\
\hline Laser power $(\mathrm{W})$ & Variable & $1-10$ \\
Laser scan speed $(\mathrm{mm} / \mathrm{s})$ & Variable & $100-10000$ \\
Part bed temperature $\left({ }^{\circ} \mathrm{C}\right)$ & Constant & 166 \\
Layer thickness $(\mathrm{mm})$ & Constant & 0.15 \\
Laser focus spot size $(\mathrm{mm})$ & Constant & 0.193 \\
Laser scan spacing $(\mathrm{mm})$ & Constant & 0.063 \\
\hline
\end{tabular}

layer thickness of powder deposition. Based on a preliminary investigation an intermediate layer thickness of $0.15 \mathrm{~mm}$ was chosen to sinter the DMA specimens. A laser scan spacing value of $0.063 \mathrm{~mm}$ was used in order to achieve an overlap of approximately 33 per cent between each scan vector as used on the commercial sinterstation. The powder bed temperature, layer thickness, laser focus spot size, and laser scan space were consistent, with different laser powers and laser scanning speeds investigated. Table 2 summarizes the settings used within this study; 15 samples were built at each parameter.

\subsection{Characterization and examination}

\subsubsection{Identification of the highest means of $\mathrm{HA}$ incorporation within the matrix material}

An eliminating variable approach was used to identify the most suitable amount of HA content ratio within the matrix of the composite material. The suitability of composite material with different HA content ratios for laser sintering each ratio was determined by the robustness of the part.

To quantify the actual amount of HA within the matrix material the ash content of powders was measured on the basis of the principles of ISO 3451-4. This involves the burning of PA and treating the HA residue at a high temperature (i.e. $650^{\circ} \mathrm{C}$ )

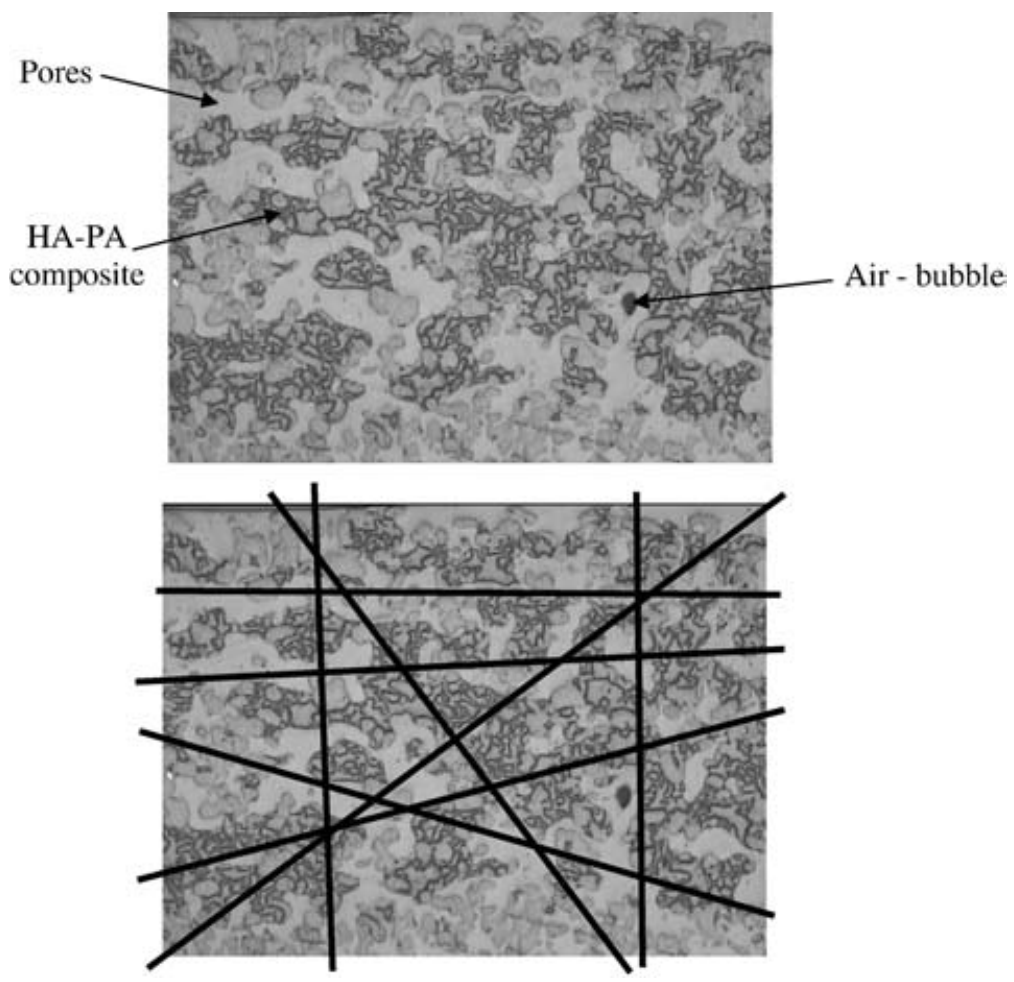

Fig. 2 Assessment of the pore structure using the interception method 
until a constant mass is reached. The amount of ash was determined by weighing the powders before and after burning. The average ash content was determined from three measurements.

\subsubsection{Apparent density and open porosity}

The apparent densities and open porosity of the sintered specimens were calculated by measuring the weight and volume of sintered parts using a balance and a $25 \mathrm{~cm}^{3}$ density bottle at $20{ }^{\circ} \mathrm{C}$ in accordance with BS 733. The average density was obtained from eight measurements. From these measurements the mean value and standard deviation were calculated and recorded.

\subsubsection{Particle analysis and surface morphology}

The particles of HA-PA composite powders and surface morphologies of the specimens were examined with an LEO 440 scanning electron microscope. Voltages below $20 \mathrm{kV}$ were used to minimize thermal damage. All samples were sputter coated with $\mathrm{Au}-\mathrm{Pd}$ to avoid charging.

\subsubsection{Pore size analysis}

The internal structure was examined by resin encasement and destructive cross-sectioning using optical microscopy. Three samples of each parameter were mounted in red epoxy resin (Epocolour, Buehler, UK). To analyse the matrix pore structure, samples were clipped in plastic sample clips and placed in a compartment. A resin was poured into each compartment until the sample was submerged. Air inclusion was evacuated by a vacuum of $200 \mathrm{mbar}$ for $5 \mathrm{~min}$. The infiltrated samples were then left overnight to set. Once set, samples were cut back approximately $1 \mathrm{~mm}$ and polished to obtain the required cross-sections for analysis.

The interception method based on BS EN 62-3: 2001 was used to assess the pore structure of the samples. This involves drawing random lines across the image, as shown in Fig. 2. These lines are then used as benchmarks across which measurements of pores are taken. Multiple cross-sections were taken in order to obtain a minimum of 500 measurements for each parameter. From these measurements the mean and percentile values were recorded.

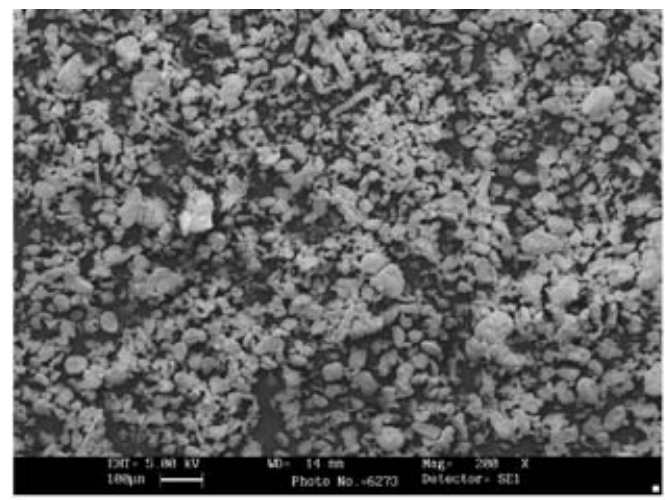

(a)

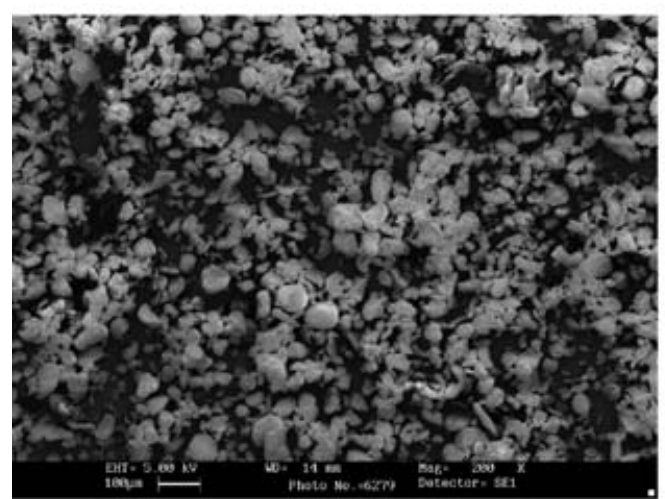

(c)

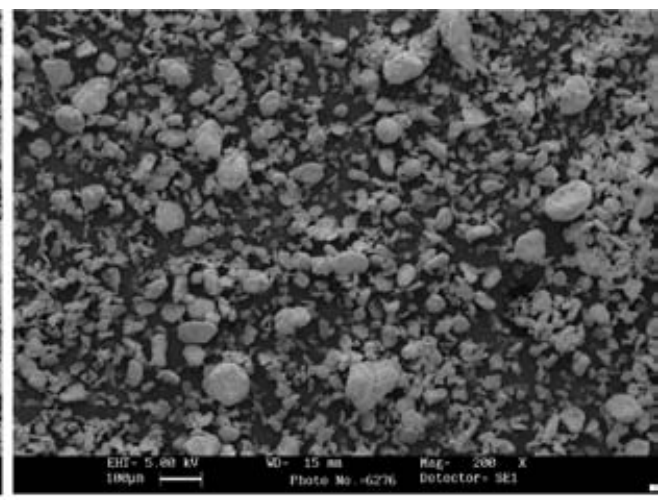

(b)

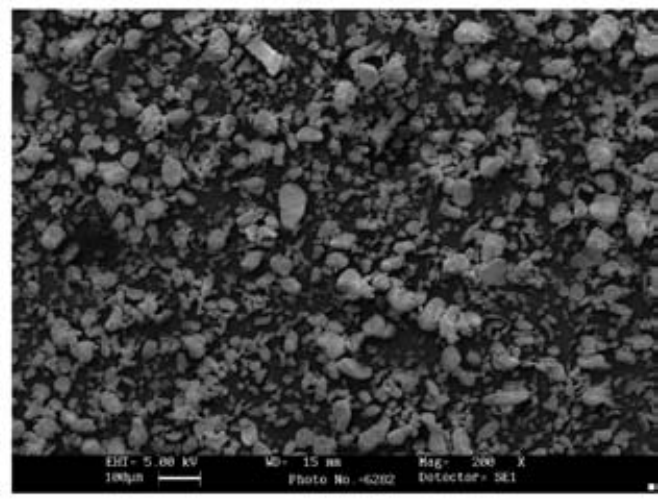

(d)

Fig. 3 Scanning electron micrograph of (a) 78 wt \% HA ratio, (b) 72 wt \% HA ratio, (c) 64 wt \% HA ratio, and (d) $58 \mathrm{wt} \%$ HA ratio composite powders 


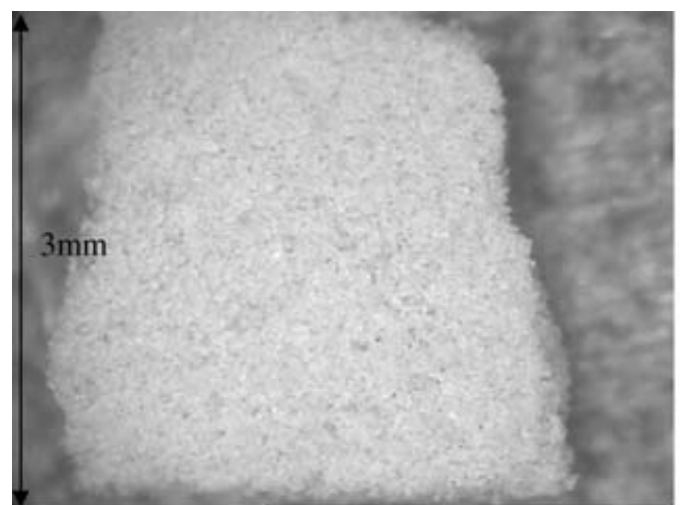

(a)

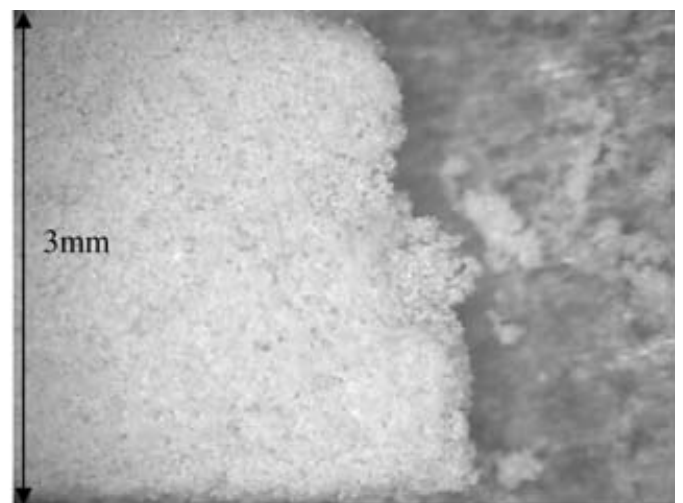

(b)

Fig. 4 (a) A specimen sintered at a laser power of $10 \mathrm{~W}$ and a laser scan speed of $1500 \mathrm{~mm} / \mathrm{s}$ and (b) the same specimen after a gentle push with a scalpel

\subsubsection{Specific heat capacity}

The specific heat capacity $C_{p}$ of the powder materials was measured using a differential scanning calorimeter. The average mass of material ranged between 9 and $11 \mathrm{mg}$ conforming with BS ISO 11357-4: 2005. The temperature program was set to stabilize for $5 \mathrm{~min}$ at $0{ }^{\circ} \mathrm{C}$, followed by a ramp at the rate of $10{ }^{\circ} \mathrm{C} / \mathrm{min}$ and finally a stabilization at $190{ }^{\circ} \mathrm{C}$ for $5 \mathrm{~min}$. Each material variation was analysed three times to obtain average values.

\section{RESULTS AND DISCUSSION}

\subsection{Microscopic examination, particle size distribution, and ash test of HA-PA composite (unsintered)}

Figure 3 shows unsintered HA-PA composites of various HA ratio contents from 78 to $58 \mathrm{wt} \%$. It was observed that most particles were irregular in shape, which may arise because the powders are generated by mechanical impact in a brittle state by centrifugal milling. There is no substantial differences in the shapes of these different composite particles. The ash content tests showed that the actual amounts of $\mathrm{HA}$ in each formation are close to the theoretical values (Table 3 ).

Table 3 Ash content in the various HA-PA compositions

\begin{tabular}{ll}
\hline Material & $\begin{array}{l}\text { Actual HA:PA ratio } \\
(w t \%)\end{array}$ \\
\hline HA-PA I & $78.4: 21.6$ \\
HA-PA II & $71.3: 28.7$ \\
HA-PA III & $63.6: 36.4$ \\
HA-PA IV & $58: 42$ \\
\hline
\end{tabular}

\subsection{Identifying the highest possible hydroxyapatite content ratio with composite powders and its processing window}

The bioactive properties of HA elicit a response among osteoblast cells which would enable osteoconductivity and stimulate osseous repair by providing physiological minerals which could be incorporated in bone regeneration [18]. Therefore it

(a)

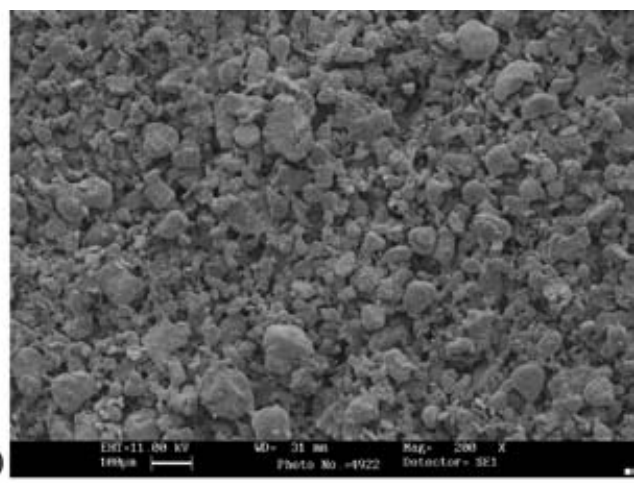

(b)

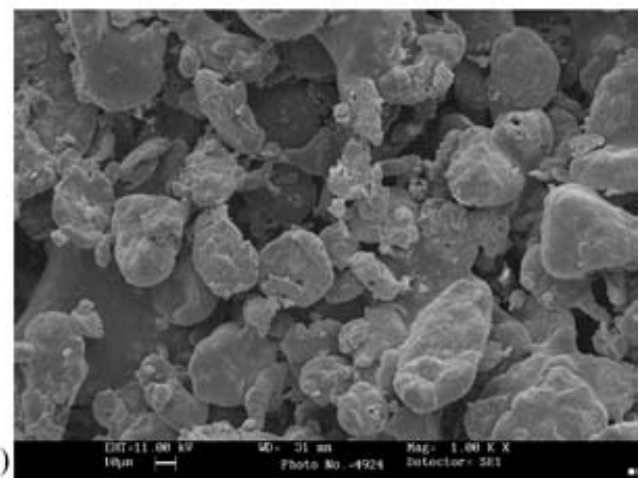

Fig. 5 Scanning electron micrographs of a fragile specimen laser sintered at $10 \mathrm{~W}$ laser power and $5050 \mathrm{~mm} / \mathrm{s}$ at (a) a low magnification (marker bar, $100 \mu \mathrm{m}$ ) and (b) a high magnification (marker bar, $10 \mu \mathrm{m}$ ) 
is considered that a high HA content would increase bioactivity and osseointegration. Table 3 illustrates the various HA weight ratio contents explored and identified the highest possible HA weight ratio in composite materials which can be sintered as acceptable parts. Sintered samples were broadly assessed in two categories on the basis of their reaction to physical handling: successful sintering withstands manual handling indicating interparticulate fusion, or unsuccessful sintering failed upon manual handling indicating lack of interparticulate fusion. Samples containing HA weight contents of 78, 71, and $64 \mathrm{wt} \%$ were too fragile to handle after sintering. Figure 4 illustrates the fragility of a part made with a maximum laser power of $10 \mathrm{~W}$ and a laser scan speed of $1500 \mathrm{~mm} / \mathrm{s}$. Figures 5(a) and (b) are scanning electron micrographs of similar specimens at low and high magnifications respectively. It is clear that a large number of individual particles were not fused at these low laser scan speed parameters even with a high power input. Conversely, material with 58 wt \% HA ratio produced successfully sintered parts in large ranges of laser powers and scanning speeds. The processing window of material containing this ratio is shown in Fig. 6. This indicates that the amount of HA greatly influences the degree of sintering, this can be explained by the change in the specific heat capacity of the material and the amount of polymer (Fig. 7). The specific heat capacity $C_{p}$ is the amount of energy required by a material speci-

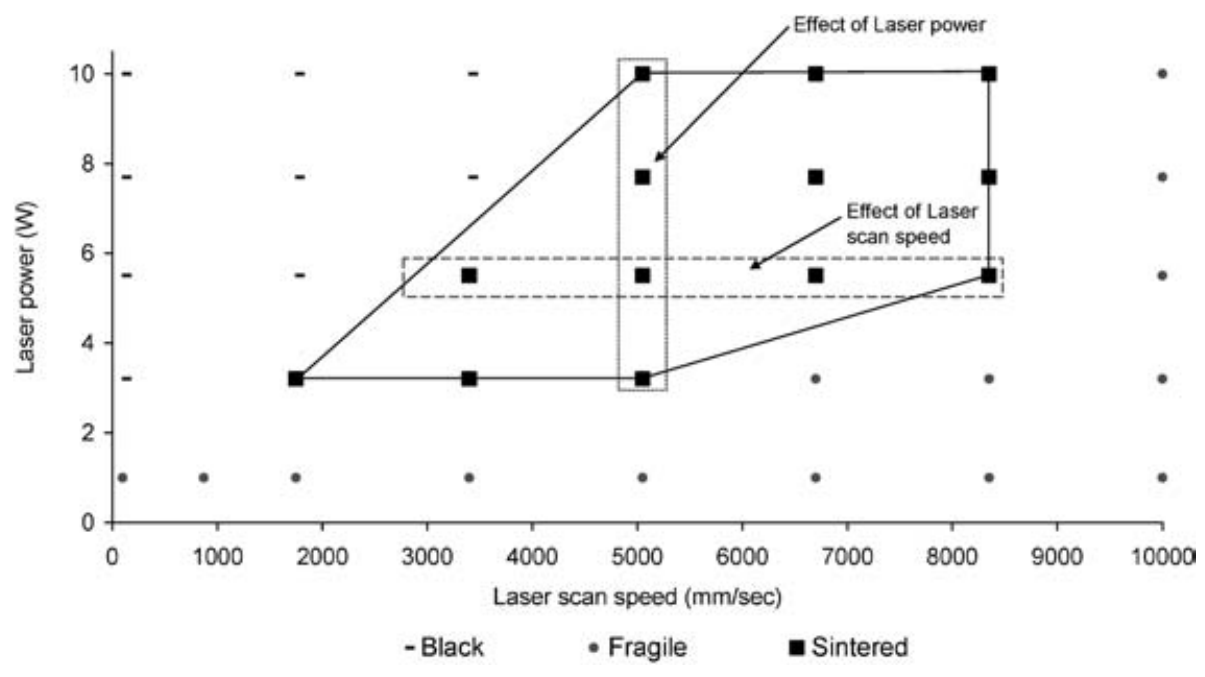

Fig. 6 Processing window for a 58:42 HA:PA weight ratio specimen

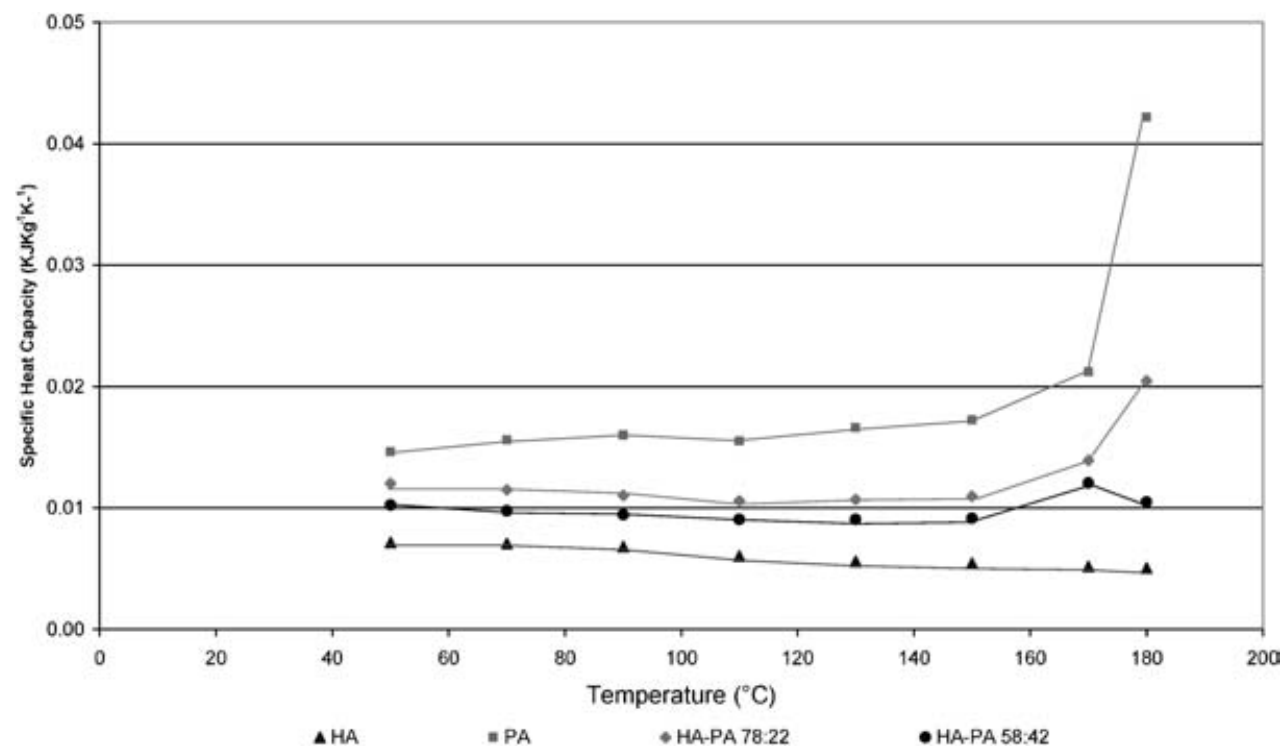

Fig. 7 Specific heat capacities of the different powders at different temperatures 
men to raise the material temperature by $1 \mathrm{~K}$. At a higher HA ratio, the $C_{p}$ of the material is reduced, indicating that the amount of heat that the material requires to raise the material's temperature by $1 \mathrm{~K}$ was less, hence there would be less stored heat within the sintering system, resulting in less conduction of heat during the sintering process and less fusion between particles. The experimental $C_{p}$ values match well with a rule of mixtures used in previous laser sintering models for composite materials [19] and given by

$$
C_{p(\mathrm{HA}-\mathrm{PA})}=\xi C_{p(\mathrm{PA})}+(1-\xi) C_{p(\mathrm{HA})}
$$

where $\xi$ is the weight fraction of the polymer binder, $C_{p(\mathrm{HA}-\mathrm{PA})}$ is the specific heat of the composite material, $C_{p(\mathrm{HA})}$ is the specific heat of HA, and $C_{p(\mathrm{PA})}$ is the specific heat of PA. Previous literature has indicated that the sintering of material with respect to porosity is highly influenced by material heat capacity [20, 21].

Meanwhile, higher weight percentage of HA means less binder and consequently less material to fuse and facilitate composite particulate bonding.

It should also be noted that this ratio correlates closely to the 60:40 HA:PLLA weight ratio used by Cruz and Simoes [22]. Their previous study showed that PLLA with a content below 30 wt \% will not be sufficient to add ductility properties to the parts, and higher than 50 wt \% resulted in implants which are too plastic and therefore do not behave as bone tissue [22].

\subsection{Processing window of HA-PA}

Among the various sintering parameters, the laser power and laser scan speed directly determine the amount of energy imparted on the part bed in the SLS process and are directly related to the specific energy density, which is the most important parameter in selective laser sintering [18]. The amount of energy absorbed is determined by the duration of radiation on a unit area. Since the energy density is a function of both the laser beam power and the laser scan speed, the processing window was determined experimentally by varying the laser power and the laser scan speed. Figure 6 illustrates the power and laser scan speed ranges in which sintering takes place. The energy density is in the range from 0.004 to $0.013 \mathrm{~W} / \mathrm{mm}^{2}$ as calculated from equation (1). When the energy density values were below $0.004 \mathrm{~W} / \mathrm{mm}^{2}$, the specimens could not be sintered or were too fragile to handle. When the energy density values were higher than $0.013 \mathrm{~W} / \mathrm{mm}^{2}$, smoke was observed during the build process and the specimens became dark brown or black, possibly because of charring of the material. This was more evident on the surface morphology of sintered parts. Figure 8 illustrates the change in the surface morphologies of fused parts at the various power settings. At high laser powers of $10 \mathrm{~W}$ the particle surface appears erupted in comparison with smooth surface particles observed for parts at $5.5 \mathrm{~W}$.

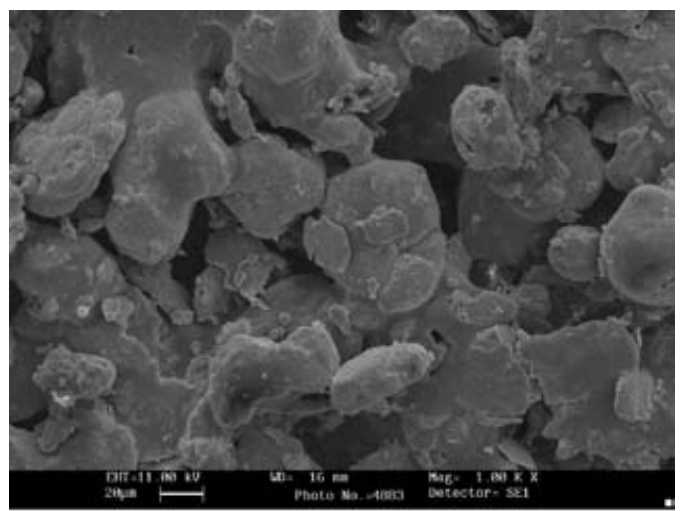

(a)

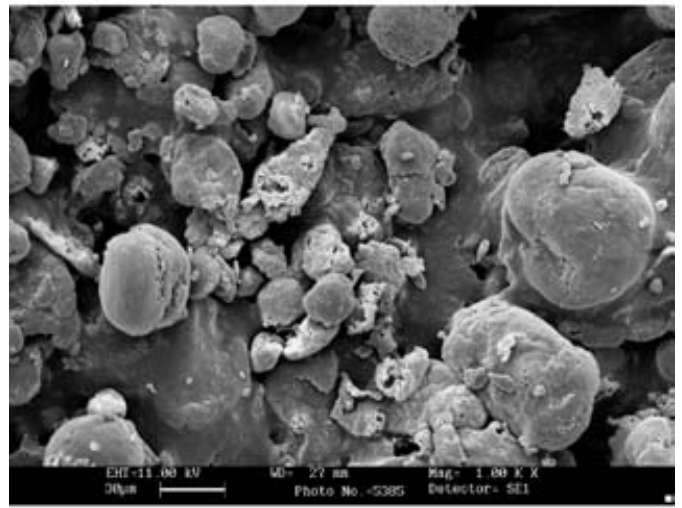

(b)

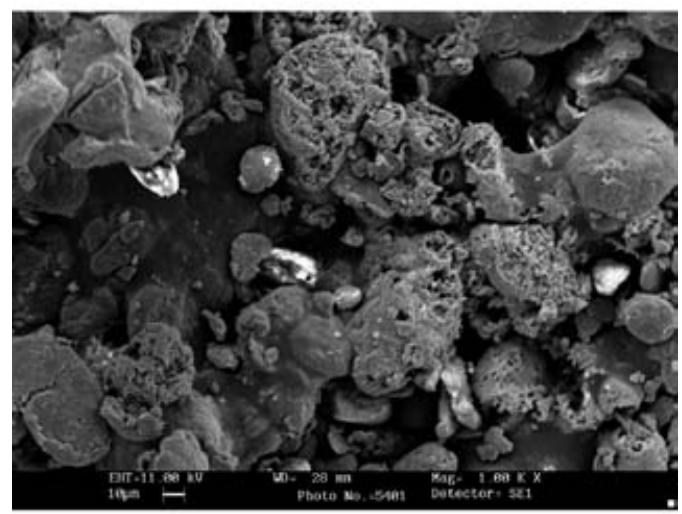

(c)

Fig. 8 Scanning electron micrographs of the surface morphologies of a $58 \mathrm{wt} \%$ HA ratio composite for laser powers of (a) $5.5 \mathrm{~W}$, (b) $7.7 \mathrm{~W}$, and (c) $10 \mathrm{~W}$ at a scanning speed of $5050 \mathrm{~mm} / \mathrm{s}$ 


\subsection{Effect of the power}

\subsubsection{Effect of power on apparent density and open porosity}

The apparent density of a specimen may be determined by its weight-to-volume ratio. The weight and volume were determined by a balance and a liquid displacement bottle. As shown in Fig. 9(a) variation in power from 3.2 to $10 \mathrm{~W}$ results in variation in the apparent density. It is clear that the lowest apparent density was found in specimens sintered at $3.2 \mathrm{~W}$. This apparent density continued to increase until $5.5 \mathrm{~W}$. However, a stabilization in the apparent density was evident up to a power of approximately $7 \mathrm{~W}$. Any further increase resulted in a slight decrease in apparent density. Previous studies revealed that the apparent density of laser sintered polycarbonate and iron powder increased with increasing energy density until a critical energy input is reached [23].

From these values the open porosity (percentage) of specimens was calculated according to

$$
\begin{aligned}
& \text { Open porosity } \\
& =\frac{\text { theoretical density }- \text { apparent density }}{\text { theoretical density }}
\end{aligned}
$$

The theoretical density is calculated according to the component volume content and density of each component. (The theoretical density of HA-PA with 30 vol $\%$ HA equals 30 per cent $\times 3.162 \mathrm{~g} / \mathrm{cm}^{-3}$ (density of HA) +70 per cent $\times 0.97 \mathrm{~kg} / \mathrm{mm}^{3}$ (density of $\left.\mathrm{PA}\right)=$ $1.62 \mathrm{~g} / \mathrm{cm}^{-3}$ ). Based on these calculations, the open

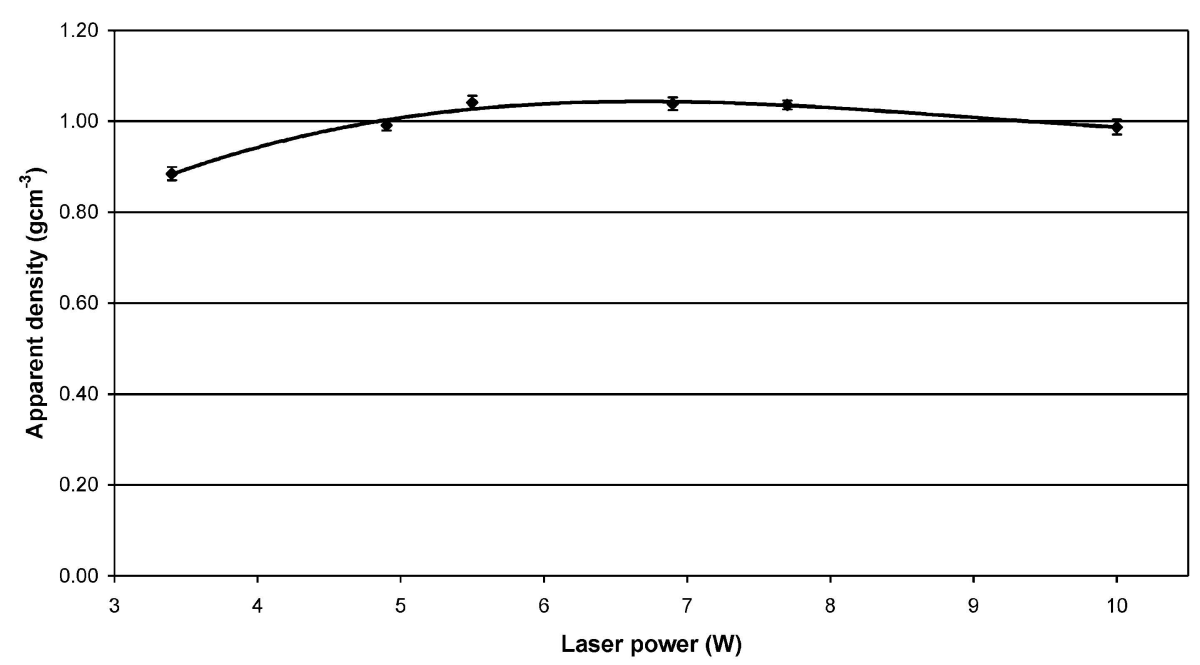

(a)

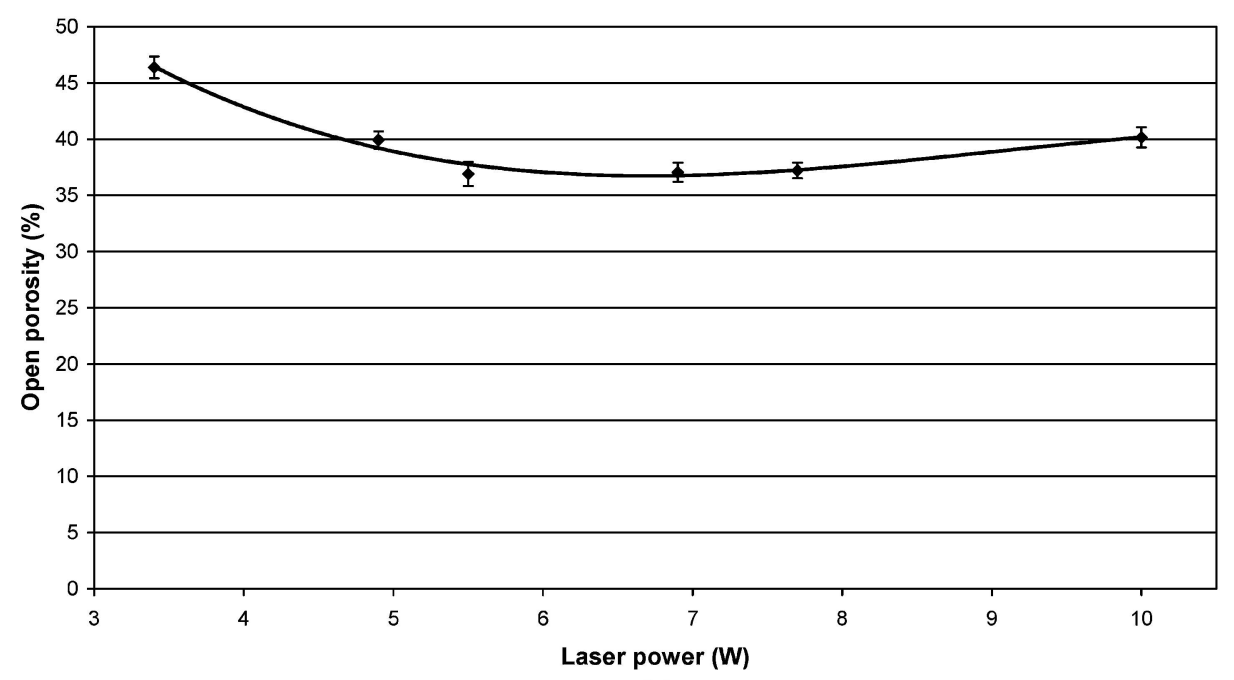

(b)

Fig. 9 The effect of the laser power on (a) the apparent density $\left(\mathrm{gcm}^{-3}\right)$ and (b) the open porosity (\%) at a laser scan speed of $5050 \mathrm{~mm} / \mathrm{s}$ 
porosity ranges in the approximate region from 36 to 45 per cent by varying the laser power (see Fig. 9 (b)).

\subsubsection{Effect on the average pore size and fraction of optimum pore sizes}

The fabrication of an ideal internal structure would enable cells to spread, proliferate, and regenerate bone. An ideal microstructure for bone regeneration is usually associated with its degree of porosity, pore size, and pore interconnectivity $[\mathbf{1 0}, \mathbf{2 4}]$. Previous studies have illustrated that, in general, a pore size of $5-11 \mu \mathrm{m}$ enables the ingrowth of fibrous tissue; pore sizes in the range $20-60 \mu \mathrm{m}$ are ideal for cell spreading and proliferation; however, a minimum pore size of approximately $100 \mu \mathrm{m}$ is considered sufficient to enable bone tissue regeneration to occur [24-28]. A fully interconnected pore network would allow cell migration and effective nutrient transport $[29,30]$. Highly porous components would provide a high surface area which could facilitate cell attachment and growth [30].

Figure 10 demonstrates representative crosssections of the specimens at the various power settings. Figure 11 illustrates representative highermagnification cross-sections of the specimens.
Table 4 Average pore size with a 58 wt \% HA ratio composite and laser powers of 3.4, 5.5, 7.7, and $10 \mathrm{~W}$ at a scanning speed of $5050 \mathrm{~mm} / \mathrm{s}$

\begin{tabular}{lll}
\hline $\begin{array}{l}\text { Laser power } \\
(\mathrm{W})\end{array}$ & $\begin{array}{l}\text { Average pore size } \\
(\mu \mathrm{m})\end{array}$ & $\begin{array}{l}\text { Amount of pores that will } \\
\text { facilitate bone regeneration } \\
(\%)\end{array}$ \\
\hline 3.4 & 61 & 19 \\
5.5 & 66 & 21 \\
7.7 & 64 & 22 \\
10 & 67 & 21 \\
\hline
\end{tabular}

Table 4 summarizes the average pore size of structures manufactured at the various power settings using the interception method. Results demonstrated that the average pore size at the various settings result in average pore sizes between 61 and $67 \mu \mathrm{m}$, showing that a 9 per cent variation was attained by varying power settings. In comparison with the effect of power on open porosity, it was clear that the effect on the average pore size and fraction of optimum pores for bone regeneration was not significant. This is possibly because the pore formation and its size are more dependent on the particle size, shape, and morphology and less dependent on the process parameters. Previous studies have indicated

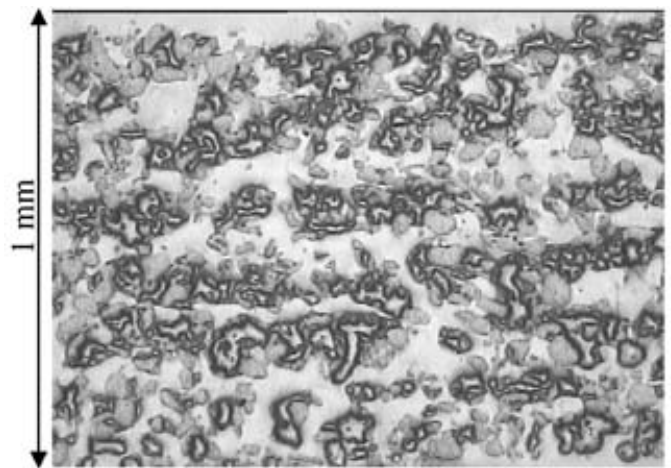

(a)

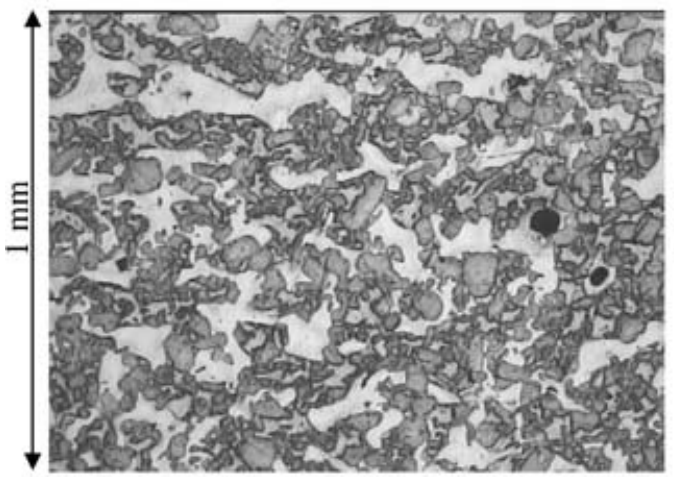

(c)

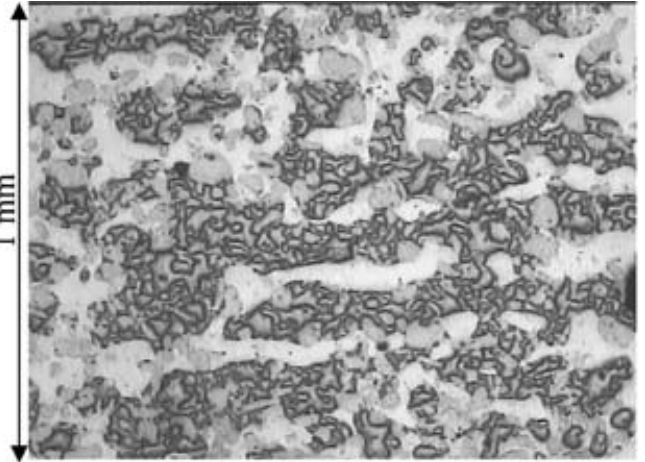

(b)

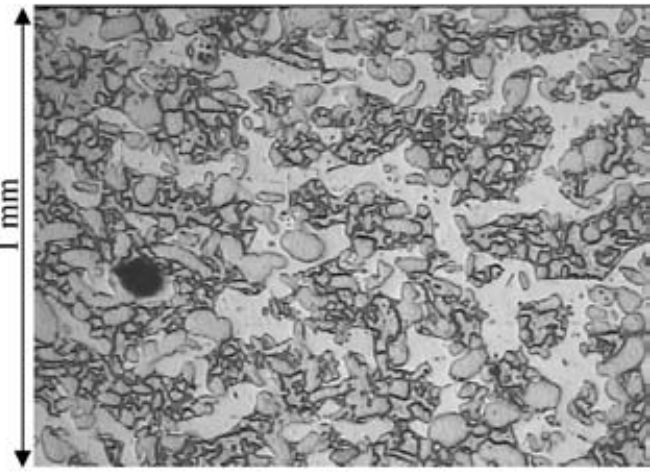

(d)

Fig. 10 Optical micrographs of cross-sections of a $58 \mathrm{wt} \%$ HA ratio composite for laser powers of (a) $3.2 \mathrm{~W}$, (b) $5.5 \mathrm{~W}$, (c) $7.7 \mathrm{~W}$, and (d) $10 \mathrm{~W}$ at a scanning speed of $5050 \mathrm{~mm} / \mathrm{s}$ 

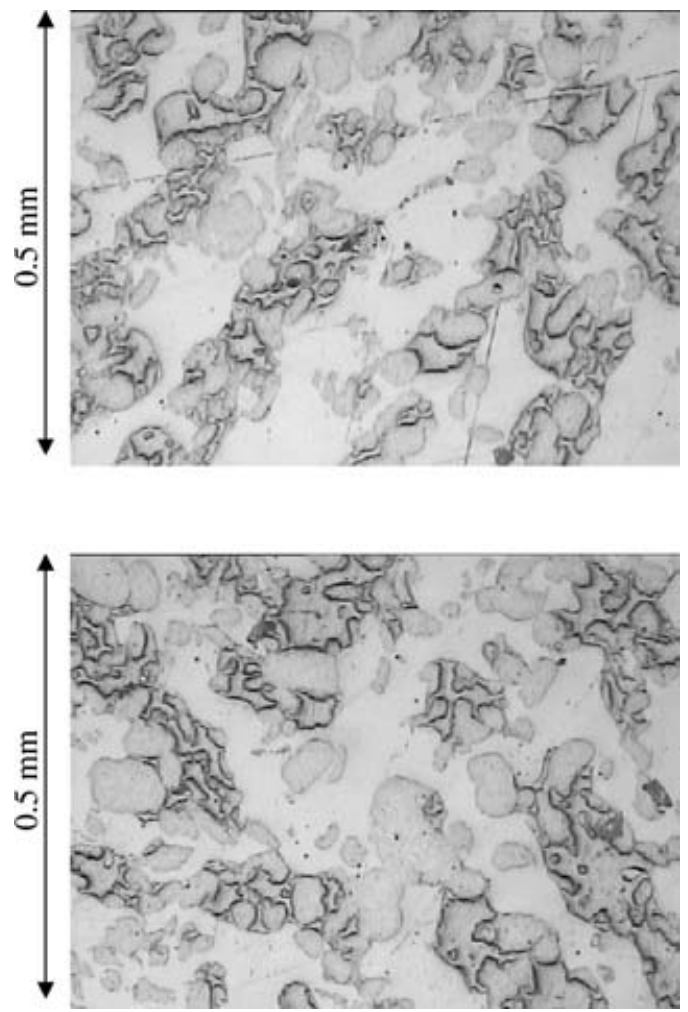

Fig. 11 Optical micrographs of the cross-sections of a $58 \mathrm{wt} \%$ HA ratio composite for laser powers of (a) $3.2 \mathrm{~W}$, (b) $5.5 \mathrm{~W}$, (c) $7.7 \mathrm{~W}$, and (d) $10 \mathrm{~W}$ at a scanning speed of $5050 \mathrm{~mm} / \mathrm{s}$

the importance of the particle size and particle size distribution [31-33].

In relation to manufacturing bioactive implants, the average pore size was in the higher region of that required for cell spreading and proliferation and only 60 per cent of that required for bone regeneration. Table 4 illustrates that approximately 20 per cent of the pores attained were suitable for bone regener- ation at the various power settings. The effect of power was minimal in altering the microstructure. However, the current structures would be suitable for cell spreading and proliferation.

\subsection{Effect of the laser scan speed}

\subsubsection{Effect on the apparent density and open porosity}

Figure 12 illustrates the effect of the laser scan speed on the open porosity. The open porosity ranged between 34 and 46 per cent and was found in samples by varying the laser scan speed. The highest amount of open porosity of approximately 46 per cent was seen in samples built at a velocity of $6700 \mathrm{~mm} / \mathrm{s}$. Although the range of open porosity values was slightly larger than that found by varying the power, the variation was erratic. Hence, this is unlikely to be a key factor that would enable the open porosity to be predicted in HA-PA parts.

\subsubsection{Effect on the average pore size, fraction of pores within the size range required for bone regeneration}

Figure 13 illustrates representative cross-sections of specimens at various laser scan speed settings. Table 5 summarizes the average pore sizes of structures manufactured at the various laser scan speed settings using the interception method described in section 2.3.4. Results demonstrated that the average pore size and the fraction of pores which could facilitate bone regeneration at the various settings were in the same region as that of variation in the power settings. Therefore it can be demonstrated that the relative energy density induced by the laser relates to the amount of HA present in the material, with an

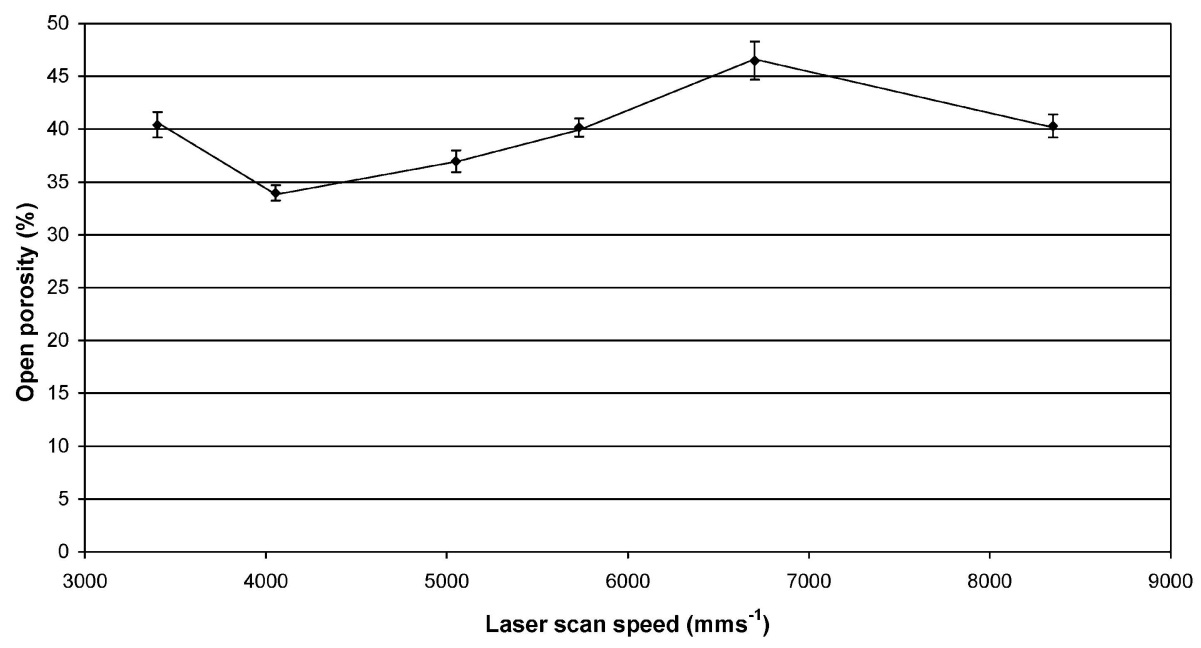

Fig. 12 The effect of the laser scan speed on the open porosity at a laser power of $5.5 \mathrm{~W}$ 


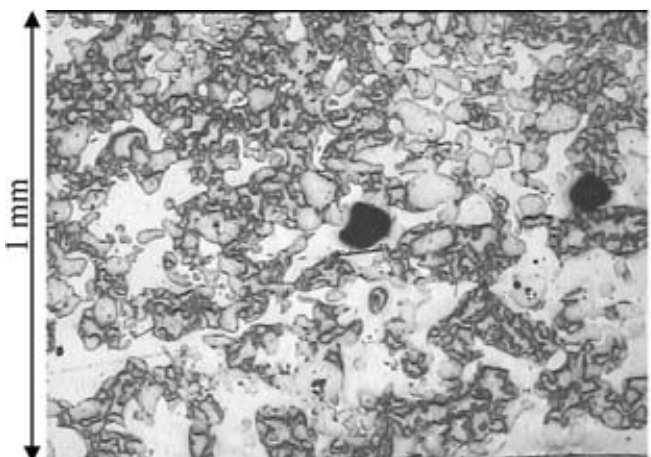

(a)

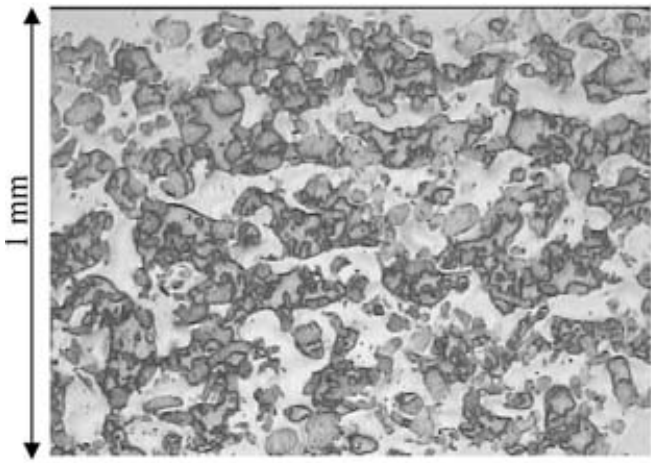

(c)

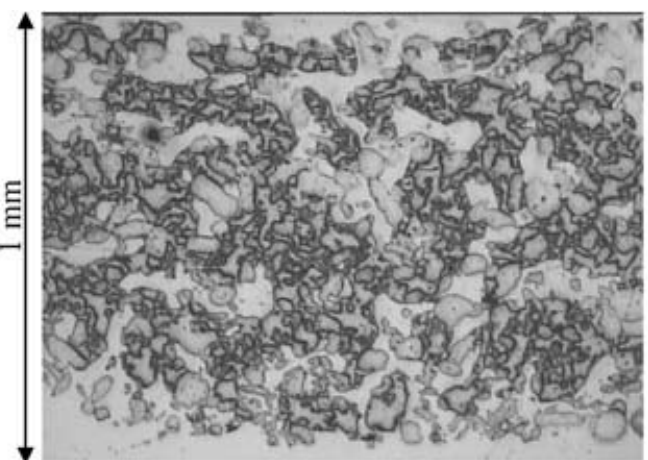

(b)

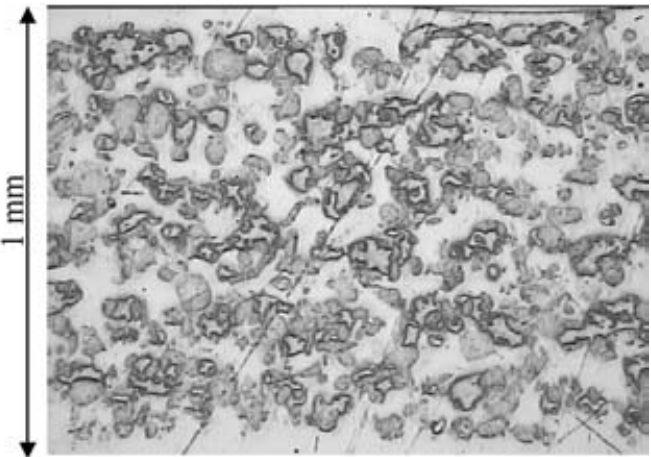

(d)

Fig. 13 Optical micrographs of the cross-sections of a 58 wt \% HA ratio composite for laser scan speeds of (a) $3400 \mathrm{~mm} / \mathrm{s}$, (b) $5050 \mathrm{~mm} / \mathrm{s}$, (c) $6700 \mathrm{~mm} / \mathrm{s}$, and (d) $8350 \mathrm{~mm} / \mathrm{s}$ at a laser power of $5.5 \mathrm{~W}$

Table 5 Average pore size with a 58 wt \% HA ratio composite and laser scan speeds of 3400,5050 , 6700 , and $8350 \mathrm{~mm} / \mathrm{s}$ at a laser power of $5.5 \mathrm{~W}$

\begin{tabular}{lll}
\hline $\begin{array}{l}\text { Laser scan } \\
\text { speed } \\
(\mathrm{mm} / \mathrm{s})\end{array}$ & $\begin{array}{l}\text { Average pore size } \\
(\mu \mathrm{m})\end{array}$ & $\begin{array}{l}\text { Amount of pores that will } \\
\text { facilitate bone regeneration } \\
(\%)\end{array}$ \\
\hline 3400 & 60 & 18 \\
5050 & 66 & 21 \\
6700 & 68 & 21 \\
8350 & 68 & 21 \\
\hline
\end{tabular}

increased volume fraction of HA (Fig. 7), less energy is required to fuse the HA-PA.

Hence, the relation of the structures with respect to the application is as suggested with the variation in the power settings. Figure 7 demonstrates that the relative energy density induced by the laser relates to the amount of HA present in the material. Materials with high HA content would require less energy to fuse; therefore the absorption of the input energy is reduced.

\section{CONCLUSIONS}

This research demonstrated the potential of SLS to fabricate a bioactive structure which contains a high
HA content and open porosity. There is a large range of laser powers and scanning speeds to sinter acceptable parts using an HA-PA composite with 58 wt \% HA. The open porosity of the sintered samples at various laser processing parameters is in the range 35-46 per cent. The cross-sectional analysis indicates that the pores are interconnected and the average size of internal pores is $60-68 \mu \mathrm{m}$ with approximately 20 per cent of the pores larger than $100 \mu \mathrm{m}$ and thus exhibiting the potential for bone regeneration. The variations in the laser power and the laser scan speed could facilitate a degree of control over the porosity and morphology of the pore, i.e. an increase of 9 per cent in the average pore size. Such limited variation in the structure is discussed with respect to the alteration in material specific heat capacity properties with the inclusion of HA particles.

\section{ACKNOWLEDGEMENTS}

The authors would like to express their gratitude for financial support from the UK Department of Health's New and Emerging Applications of Technology programme (NEAT E059). 


\section{REFERENCES}

1 Koc, N., Timuçin, M., and Korkusuz, F. Fabrication and characterization of porous tricalcium phosphate ceramics. Ceram. Int., 2004, 30(2), 205-211.

2 Hutmacher, D. W., Rohner, D., Yeow, V., Lee, S. T., Brentwood, A., and Schantz, J.-T. Craniofacial bone tissue engineering using medical imaging, computational modeling, rapid prototyping, bioresorbable scaffolds and bone marrow aspirates. In Proceedings of the NATO Advanced Study Institute on Polymer based systems on tissue engineering, replacement and regeneration (Eds P. L. Reis and P. Cohn), Alvor, Algarve, Portugal, 15-25 October 2001, 2002, pp. 333-356 (Kluwer, Dordrecht).

3 Furlong, R. J. and Osborn, J. F. Fixation of hip prostheses by hydroxyapatite ceramic coatings. J. Bone Jt Surg. Br., 1991, 73(5), 741-745.

4 Mercuri, L. G., Wolford, L. M., Sanders, B., White, D., Hurder, A., and Herderson, W. Custom $\mathrm{CAD} / \mathrm{CAM}$ total temporomandibular joint reconstruction system: preliminary multicenter report. J. Oral Maxillofacial Surg., 1995, 53, 106-115.

5 Hing, K. A., Buckland, T., and Moseley, P. Maximising osseointegration - unique bone grafting solutions for different surgical applications. Available from http://www.touchbriefings.com/pdf/33/ gs031_r_13hing.pdf.

6 Hing, K. A., Best, S. M., Tanner, K. E., Bonfield, W., and Revell, P. A. Mediation of bone ingrowth in porous hydroxyapatite bone graft substitutes. J. Biomed. Mater. Res. A, 2004, 68, 187-200.

7 Hopkinson, N. and Dickens, P. M. Analysis of rapid manufacturing - using layer manufacturing processes for production. Proc. Instn Mech. Engrs, Part C J. Mechanical Engineering Science, 2003, 217(C1), 31-39.

8 Leong, K. F., Phua, K. K. S., Chua, C. K., Du, Z. H., and Teo, K. O. M. Fabrication of porous polymeric matrix drug delivery devices using the selective laser sintering technique. Proc. Instn Mech. Engng, Part $H$ : J. Engineering in Medicine, 2001, 215(H2), 191-201.

9 Gill, T. J. and Hon, K. K. B. Experimental investigation into the selective laser sintering of silicon carbide polyamide composites. Proc. Instn Mech. Engrs, Part B: J. Engineering Manufacture, 2004, 218, 1249-1256.

10 Tan, K. H., Chua, C. K., Leong, K. F., Cheah, C. M., Cheang, P., Abu Bakar, M. S., and Cha, S. W. Scaffold development using selective laser sintering of polyetheretherketone-hydroxyapatite biocomposite blends. Biomaterials, 2003, 24(18), 3115-3123.

11 Chua, C. K., Leong, K. F., Wiria, F. E., Tan, K. C., and Chandrasekara, M. Fabrication of poly(vinyl alcohol)/hydroxyapatite in tissue engineering. In Proceedings of the International Conference on Competitive manufacturing, 2004 (World Scientific Publishing Company, Steilhenbosch).

12 Das, S., Hollister, S. J., Flanagan, C., Adewunmi, A., Bark, K., Chen, C., Ramaswamy, K., Rose, D., and Widjaja, E. Computational design, freeform fabrication and testing of Nylon-6 tissue engineering scaffolds. In Rapid prototyping technologies, Materials Research Society Symposium Proceedings, Vol. 758, Boston, Massachusetts, 3-5 December 2002, pp. 205-210 (Materials Research Society, Warrendale, Pennsylvania).

13 Das, S., Hollister, S. J., Flanagan, C., Adewunmi, A., Bark, K., Chen, C., Ramawamy, K., Rose, D., and Widjaja, E. Freeform fabrication of Nylon-6 tissue engineering scaffolds. Rapid Prototyping J., 2003, 9(1), 43-49.

14 Williams, J. M., Adewunmi, A., Schek, R. M., Flanagan, C. L., Krebsbach, P. H., Feinberg, S. E., Hollister, S. J., and Das, S. Bone tissue engineering using polycaprolactone scaffolds fabricated via selective laser sintering. Biomaterials, 2005, 26(23), 4817-4827.

15 Du, Z. H., Phua, K. K. S., Leong, K. F., Chua, C. K., and Teo, K. O. M. Development of drug delivery devices using rapid prototpying technology. In Proceedings of the Eighth European Conference on Rapid prototyping and manufacturing, Nottingham, UK, 1998, pp. 269-280.

16 Wang, M., Porter, D., and Bonfield, W. Processing, characterisation, and evaluation of hydroxyapatite reinforced polyethylene composites. Br. Ceram. Trans., 1994, 93, 91-95.

17 Yang, H.-J., Hwang, P.-J., and Lee, S.-H., A study on shrinkage compensation of the SLS process by using the Taguchi method. Int. J. Mach. Tools Mf., 2002, 42, 1203-1212.

18 Lee, G. Selective laser sintering of calcium phosphate materials for orthopedic implants. PhD Dissertation, The University of Texas at Austin, Austin, Texas, 1997, p. 242.

19 Nelson, J. C., Vail, N. K., and Barlow, J. W. Laser sintering model for composite materials. In Proceedings of the Symposium on Solid freeform fabrication, Austin, Texas, USA, Vol. 4, 1993, pp. 360-369 (The University of Texas in Austin).

20 Childs, T. H. C., Berzins, M., Ryder, G. R., and Tontowi, A. E. Selective laser sintering of an amorphous polymer - simulations and experiments. Proc. Instn Mech. Engrs, Part B: J. Engineering Manufacture, 1999, 213(B4), 333-349.

21 Childs, T. H. C. and Tontowi, A. E. Selective laser sintering of a crystalline and a glass-filled crystalline polymer: experiments and simulations. Proc. Instn Mech. Engrs, Part B: J. Engineering Manufacture, 2001, 215(B11), 1481-1495.

22 Cruz, F. and Simoes, J. F. A. Fabrication of customised bioceramic implants using selective laser sintering. In Proceedings of the Conference on Rapid prototyping, tooling, and manufacturing, 2002, pp. 63-70 (Professional Engineering Publishing Limited, Bury St Edmunds and London).

23 Ho, H. L. H., Gibson, I., and Cheung, W. L. Effects of energy density on morphology and properties of selective laser sintered polycarbonate. J. Mater. Processing Technol., 1999, 89-90, 204-210. 
24 Yang, S. F., Leong, K. F., Du, Z. H., and Chua, C. K. The design of scaffolds for use in tissue engineering. Part 1. Traditional factors. Tissue Engng, 2001, 7(6), 679-689.

25 Hao, L., Lawrence, J., and Chian, K. S. On the effects of $\mathrm{CO}_{2}$ laser irradiation on the surface properties of a magnesia partially stabilised zirconia (MgO-PSZ) bioceramic and the subseqent improvements in human osteoblast cell adhesion. J. Biomater. Applic., 2004, 19, 81-105.

26 Karageorgiou, V. and Kaplan, D. Porosity of 3D biomaterial scaffolds and osteogenesis. Biomaterials, 2005, 26, 5474-5491.

27 Hulbert, S. F. and Klawitter, J. J. Application of porous ceramics for attachment of load bearing internal orthopedic applications. J. Biomed. Mater. Res., 1972, 2, 161-229.

28 Hollister, S. J., Maddox, R. D., and Taboas, J. M. Optimal design and fabrication of scaffolds to mimic tissue properties and satisfy biological constraints. Biomaterials, 2002, 23, 4095-4103.
29 Hutmacher, D. W. Scaffolds in tissue engineering bone and cartilage. Biomaterials, 2000, 21(24), 2529-2543.

30 Leong, K. F., Cheah, C. M., and Chua, C. K. Solid freeform fabrication of three-dimensional scaffolds for engineering replacement tissues and organs. Biomaterials, 2003, 24(13), 2363-2378.

31 Simchi, A. The role of particle size on the laser sintering of iron powder. Metall. Mater. Trans. B, 2004, 35, 937-948.

32 Savalani, M. M., Hao, L., and Harris, R. A. Evaluation of $\mathrm{CO}_{2}$ and Nd: YAG lasers for the selective laser sintering of HAPEX(R). Proc. IMechE, Part B: J. Engineering Manufacture, 2006, 220, 171-182.

33 Shi, Y., Li, Z., Sun, H., Huang, S., and Zeng, F. Effect of the properties of the polymer materials on the quality of selective laser sintering parts. Proc. Instn Mech. Engrs, Part L: J. Material Design and Applications, 2004, 218, 247-252. 